\title{
KONTROLA NAD SKLAPANJEM UPRAVNIH UGOVORA
}

\author{
UDK: $342.9(497.5$ \\ Pregledni znanstveni rad \\ Primljeno: 15. IX. 2015.
}

\begin{abstract}
Upravni ugovori u hrvatskom zakonodavstvu predstavljaju novinu uvedenu Zakonom o općem upravnom postupku 2010. godine, novinu koja se nije pokazala uspješnom u praksi. Kontrola nad sklapanjem upravnih ugovora neophodna je i vrlo značajna zbog nekoliko razloga. Prvo, javnopravna tijela koja ih sklapaju čine to izvršavajući svoje javne ovlasti, što nedvojbeno podliježe kontroli zakonitosti; drugo, u sklapanju upravnih ugovora raspolaže se javnim sredstvima što je također neophodno kontrolirati; treće, sklapanjem upravnih ugovora često se zadire u korištenje javnih dobara. Zbog restriktivnog tumačenja upravnih ugovora u hrvatskom zakonodavstvu ovaj je institut nesporno uređen samo u Općem poreznom zakonu. Međutim, u našem pravu već više od dva desetljeća postoje ugovori koji zadovoljavaju sve pretpostavke da bi se mogli smatrati upravnim ugovorima. Iz tog će se razloga u radu autor više pozabaviti kontrolom nad ugovorima koje smatra upravnim ugovorima - ugovorima o koncesijama i ugovorima o javnoj nabavi. Autor ce pokazati kako je današnje uređenje kontrole sklapanja upravnih ugovora, prvenstveno ugovora o koncesiji i ugovora o javnoj nabavi, neadekvatno i predložit će zakonodavne promjene koje će rezultirati kvalitetnijim sustavom kontrole sklapanja upravnih ugovora. Autor će pokazati i da se kontrola sklapanja upravnih ugovora ne može promatrati odvojeno od kontrole izvršavanja upravnih ugovora.
\end{abstract}

Ključne riječi: upravni ugovor, ugovor o koncesiji, ugovor o javnoj nabavi, kontrola zakonitosti

\section{UVOD}

Kontrola nad sklapanjem upravnih ugovora izrazito je značajna, budući da pri sklapanju upravnih ugovora, u pravilu, javnopravna tijela i druge pravne osobe, eventualno ovlaštene na sklapanje upravnih ugovora, izvršavaju svoje javne ovlasti. Pri sklapanju upravnih ugovora raspolaže se i sredstvima iz javnih izvora, i to u pravilu značajnim iznosima tih sredstava. Tim je važnije provoditi kontrolu nad zakonitosti sklapanja, ali i izvršavanjem upravnih ugovora kako bi se osigurala zakonitost izvršavanja javnih ovlasti, ali i zakonitost trošenja sredstava iz javnih izvora.

Kako bismo mogli analizirati kontrolu nad sklapanjem upravnih ugovora, morali bismo ponajprije znati, odnosno barem omeđiti područje o kojem govorimo, tj. imati jasnu definiciju upravnih ugovora i uspostaviti njihovo razgraničenje od ugovora građanskopravne prirode. Ova dva preduvjeta nije jednostavno ostvariti ni u hrvatskom pravu ni u usporednom pravu. Naime, vrlo su česte podjele i 
sukobi oko pravne prirode određenih ugovora, pa se u usporednim pravima često zakonom propisuje javnopravna priroda određenih ugovora.

Kada govorimo o kontroli nad sklapanjem upravnih ugovora u hrvatskom pravu, moramo imati na umu nekoliko vrlo važnih činjenica. Prvo, upravni je ugovor relativno novi institut $\mathrm{u}$ hrvatskom pravu te je sudska praksa glede njegovih učinaka praktički nepostojeća. Drugo, već se prilikom donošenja Zakona o općem upravnom postupku ${ }^{1} 2009$. godine (dalje u radu: ZUP) navodilo kako je zakonodavno rješenje upravnih ugovora u tom zakonu neadekvatno i da upravni ugovori neće zaživjeti. Naime, pri odlučivanju o zakonodavnom uređenju upravnih ugovora, pojavio se koncepcijski sukob oko sustava uređenja upravnih ugovora. Jedni su smatrali kako treba preuzeti francuski sustav, a drugi da treba preuzeti njemački sustav. Na kraju je stvoren hibridni sustav koji nije posve francuski niti posve njemački, a usudio bih se reći da je ostao nedorečen. Treće, u hrvatskoj pravnoj teoriji i sudskoj praksi postoje razmimoilaženja oko tumačenja pravne prirode nekih ugovora koje jedni svrstavaju u upravne ugovore, a drugi u građanskopravne ugovore. Paradigmatski su primjeri ugovori o javnoj nabavi i ugovori o koncesijama. Iz navedenih razmimoilaženja proizašla su i zakonodavna vrludanja glede nadležnosti za sporove koji proizlaze iz takvih ugovora. Prema tome, kada govorimo o kontroli nad sklapanjem upravnih ugovora, moramo biti svjesni navedenih činjenica, od kojih je za kvalitetu kontrole nad sklapanjem upravnih ugovora ključna činjenica da se moramo ponajprije dogovoriti oko toga što smatramo, u našem pravu, upravnim ugovorom.

\section{UPRAVNI UGOVORI - UGOVORI JAVNOG PRAVA}

U Europi postoje dva osnovna modela upravnih ugovora: francuski i njemački model. U francuskom se pravu dvije vrste upravnih ugovora smatraju najvažnijima, ugovori o javnoj nabavi (marché public) i o koncesioniranoj javnoj službi (délégations de service public). ${ }^{2}$ Međutim, ovo nisu jedine vrste upravnih ugovora u Francuskoj: mnogi su upravni ugovori proglašeni takvima zakonskom normom (les contrats administratifs per détermination de la loi), kao npr. ugovori o korištenju javnih dobara ili o javnim radovima, ${ }^{3}$ a i sudska je praksa razvila određene kriterije prema kojima se prosuđuje je li u konkretnom slučaju riječ

1 NN 47/09.

2 „Parmi tous les contrats administratifs les marchés publics et les délégations de sevice public occupent neanmoins une place essentielle." V. u: Richer, L., Droit des contrats administratifs, L.G.D.J. Paris, 2008., str. 447. Slično i Frier, P-L:, Precis de droit administratif, Montchrestien, 2003., str. 323-325. Međutim, Frier navodi i ugovore o javno-privatnom partnerstvu (partenariats publics-privés) i ugovore među javnopravnim tijelima (contrats entre personnes publiques) kao vrste upravnih ugovora. Podjelu upravnih ugovora u svom kapitalnom djelu daje i Richer koji upravne ugovore dijeli na: ugovore o javnoj nabavi, ugovore o koncesioniranoj javnoj službi, ugovore o korištenju javnog dobra, razvojne koncesije, ugovore o javno-privatnom partnerstvu i ugovore o zapošljavanju javnih službenika. V. u: Richer, L., op. cit., str. 354., opširno v. ibid, str. 355-710.

3 Frier, P-L:, op. cit., str. 328., a tako i Đerđa, D., „Posebnosti upravnih ugovora“, Hrvatska pravna revija, br. 10/2008., str. 58 . 
o upravnom ugovoru ili nije. ${ }^{4}$ Kriteriji sudske prakse su: kriterij cilja, ${ }^{5}$ kriterij posebnih odredbi ${ }^{6}$ i kriterij ugovornih strana. ${ }^{7}$

Njemačko pravo poznaje upravne ugovore, međutim, takvi se ugovori izričito ne nazivaju upravnim ugovorima (Verwaltunsvertrag), nego se oni pojavljuju kao određena vrsta javnopravnih ugovora. ${ }^{8}$ Prema njemačkom pravu, upravni su ugovori oni kod kojih se ugovor odnosi na takvu pravnu situaciju na koju se primjenjuju pravila javnog prava. ${ }^{9}$

Međutim, za razliku od francuskog prava, kod kojega je subordiniranost stranaka pri sklapanju upravnog ugovora neizbježna, njemački pravni sustav razdvojio je upravne ugovore na dvije glavne vrste: na koordinirane (koordinationsrechtliche Verträge) i subordinirane (subordinationsrechtliche Verträge) upravne ugovore. ${ }^{10}$ Subordinirani upravni ugovori su, prema §. 54. st. 2. njemačkog Verwaltungsverfahrengesetz (dalje $\mathrm{u}$ radu: $\mathrm{VwVfG}^{11}$ posebno svi javnopravni ugovori, koji se sklapaju između javne vlasti i treće osobe, a umjesto kojega bi jednako tako mogao biti donesen upravni akt. Međutim, jednako tako spadaju u subordinirane upravne ugovore i takvi ugovori koje doista ne bi zamijenio upravni akt, ali se stranke nalaze u određenom odnosu subordinacije koji doista postoji prilikom sklapanja ugovora. ${ }^{12}$

Općenito govoreći, možemo reći da se, posebno u području javne nabave, ugovori mogu klasificirati putem dvaju osnovnih modela: francuskom, u kojem je ugovor podložan pravilima javnog prava i englesko-njemačkom u kojemu je ugovor podložan pravilima privatnog prava. Međutim ovakva je oštra podjela neprikladna, pa se priklanjam stavu da postoje tri osnovna sustava:

4 Pirnat, R., „Upravni ugovor i upravni postupak“, u: Modernizacija općeg upravnog postupka $i$ javne uprave u Hrvatskoj, Suvremena javna uprava, Zagreb, 2009., str. 112.

5 „... upravni ugovori su oni kojih je cilj obavljanja javne službe; pritom sudska praksa naglašava da nije upravni ugovor svaki ugovor na temelju kojeg ugovorna stranka sudjeluje ili pristupa obavljanju javne službe, nego da je upravni ugovor onaj kojim jedna strana stječe određeno pravo ili obvezu, djelomično ili u cijelosti, neposredno obavljati javnu službu." V u: ibid.

6 „„.. upravni ugovori su oni u kojima je moguće naći odredbe koje ne spadaju u okvir privatnog prava; Conseil d'Etat (Državni savjet) te je odredbe definirao kao „bilo koju odredbu ugovora koja ugovornim stranama daje prava ili nalaže obveze koje uobičajeno u okviru privatnoga ili trgovačkog prava ne bi nitko slobodno ugovorio."V. u: ibid.

7 „,.. u pravilu barem jedna strana iz upravnog ugovora mora biti osoba javnog prava kako bi se moglo govoriti o upravnom ugovoru; ako su obje ugovorne stranke osobe javnog prava, riječ je o upravnom ugovoru neovisno o njegovom sadržaju. "V u: ibid.

8 Johlen, H., Verwaltungsrecht, Verlag C.H. Beck, München, 2009., str. 429., Kirchof, P. i KruterKirchof, C., Staats- und Verwaltungsrecht Bundesrepublik Deutschland, C.F. Muller Verlag, Heilderberg, 2009., str. 29.(vwVfG 40). Tako i Medvedović, D., „Bitne razlike novog ZUP-a prema prijašnjem ZUP-u“, u: Primjena Zakona o općem upravnom postupku, Informator, Zagreb, 2010., str. 52, Borković, I., „Upravni ugovori“, Zbornik Pravnog fakulteta u Splitu, god 30/2, 1993., str. 418.

9 Detterbeck, S., Öffentliches Recht, Verlag Franz Vahlen, München, 2009., str. 341.

10 Tako i ibid, str. 342-343.

11 BGB1. I S. 102, BGB1. I S. 2749.

12 Dettterbeck, S., op. cit., str. 342-343. 
1) francuski u kojem javni ugovori (contrats publics) imaju posebnu pravnu prirodu i spadaju u krug javnog prava te su za sporove koji iz njih proizlaze nadležni specijalizirani upravni sudovi,

2) britanski u kojemu se ugovori koje sklapa javna uprava ne razlikuju od onih koje sklapaju osobe privatnog prava te su za sporove koji iz njih proizlaze nadležni redovni sudovi i

3) sustav razvijen u Italiji, Njemačkoj i Nizozemskoj u kojem se smatra da je ugovor što ga sklapa javna uprava privatnopravne naravi, ali su podložni raznim posebnim pravilima. Iznimke od općeg pravila (primjena privatnog prava) ponekad su toliko široke da se s pravom može sumnjati u privatnopravnu narav takvih ugovora. Međutim, za sporove koji proizlaze iz tih ugovora nadležni su redovni sudovi, a ne posebni specijalizirani upravni sudovi. ${ }^{13}$

Međutim, kada promotrimo cjelokupni postupak sklapanja javnih ugovora u Europi, vidjet ćemo kako se navedena podjela odnosi samo na fazu sklapanja samog ugovora, a ne i na postupak koji prethodi sklapanju ugovora. Ova činjenica proizlazi iz toga što je postupak koji prethodi sklapanju ovakvih ugovora, a uzmimo za primjer javnu nabavu kao ugovor čija je pravna priroda kod nas „najspornija“, uređen pravilima javnog prava, bez iznimke. Ovo posebno proizlazi iz činjenice da je taj postupak uređen zakonodavstvom $\mathrm{EU}^{14} \mathrm{i}$ da se pri sklapanju takvih ugovora uvijek mora voditi računa o javnom interesu. ${ }^{15}$

U ovom ću se radu voditi navedenom klasifikacijom kako bih objasnio svoj stav da se, uz upravni ugovor koji se sklapa prema Općem poreznom zakonu (dalje u radu: OPZ) ${ }^{16}$ i drugi ugovori u hrvatskom pravu mogu smatrati upravnim ugovorima. Naime, koliko mi je poznato, jedini ugovori koji potpuno zadovoljavaju sve kriterije koje ZUP postavlja kako bi se neki ugovor smatrao upravnim ugovorom, jesu oni koji su (odnosno koji će se tek sklapati, budući da mi nije poznato da se do sada ijedan sklopio) propisani OPZ-om. Kriteriji koje ugovor mora zadovoljiti kako bi se smatrao upravnim ugovorom propisani su ZUP-om: mora mu prethoditi donošenje rješenja o upravnoj stvari, ugovorom se javnopravno tijelo i stranka sporazumijevaju o izvršenju prava i obveza utvrđenih u rješenju i sklapanje upravnog ugovora mora biti propisano zakonom. Prevladavajuće je mišljenje kako, da bi se ugovor smatrao upravnim, mora u zakonu biti propisano da se radi o upravnom ugovoru, bez obzira na to što ugovor inače zadovoljava sve karakteristike koje krase upravne ugovore. Dakako, s navedenim prevladavajućim se mišljenjem ne slažem te smatram kako se i mnoge

13 Comba, M. E., „Contract Execution in Europe: Different Legal Models with a Common Core“, European Procurement \& Public Private Partnership Law Review, 4/2013., str. 304.

14 Direktiva 2004/18/EC, SL L 134 od 30. travnja 2004., koja uređuje javnu nabavu u području javnih radova, javnih usluga i nabave u javnopravnim tijelima te Direktiva 2004/17/EC, SL L 134 od 30. travnja 2004. koja uređuje javne nabave u područjima vodoopskrbe, energetike, transporta i poštanskih usluga. Donesena je i nova Direktiva 2014/24/EU, SL L 94/65 od 26. veljače 2014. koja stupa na snagu 18. travnja 2016. godine i kojom se stavlja izvan snage Direktiva 2004/18/EC od 31. ožujka 2004.

15 Comba, M. E., op. cit., str. 305.

16 NN 147/08, 18/11, 78/12, 136/12, 73/13 i 26/15. 
druge ugovore u hrvatskom pravu može smatrati upravnim ugovorima. ${ }^{17}$ Ovo ponajprije vrijedi za ugovore o koncesijama, čijem sklapanju prethodi upravni postupak, ${ }^{18}$ kao i za ugovore o javnoj nabavi čijem sklapanju također prethodi donošenje upravnog akta (rješenja). ${ }^{19}{ }^{20}$ Prema tome, kod navedenih ugovora najprije se donosi rješenje, protiv kojega je dopušteno izjaviti žalbu, pa se po izvršnosti ${ }^{21}$ odluke o koncesiji odnosno odluke o odabiru sklapa ugovor. Zbog toga ću u radu za navedene ugovore koristiti izraz ,javni ugovori“, koji je, prema mojem mišljenju, sinonim ZUP-ovu izrazu ,upravni ugovor“. Ugovori spomenuti supra, tj. ugovor o koncesiji i ugovor o javnoj nabavi, nedvojbeno imaju snažnu karakteristiku ostvarivanja javnog interesa u sklapanju i izvršavanju tih ugovora, pri čemu treba posebno naglasiti ovu komponentu kod ugovora o javnoj nabavi.

Međutim, kako o tome ne postoji konsenzus, postavlja se pitanje kontrole javnih (upravnih) ugovora koji se nedvojbeno odnose na javno pravo, odnosno uređuju odnose koji mu pripadaju. Naime, u našem se pravu uobičajilo, za niz ugovora koje bih osobno smatrao upravnim ugovorima, propisati, u slučaju spora, nadležnost redovnih sudova. Zbog ove je činjenice, kontrola većine ugovora koji bi se mogli (morali) smatrati upravnim ugovorima u rukama redovnih sudova. Iz navedene činjenice proizlazi i otežana kontrola zakonitosti naknadnih radnji, jednom kada je ugovor sklopljen. Naime, ako smatramo da je neki ugovor građanskopravne prirode, onda se on može mijenjati dogovorom stranaka, a treće osobe ne mogu osporavati takve izmjene, osim u određenim zakonom propisanim slučajevima. Dodatno, danas postoji niz direktiva koje uređuju sklapanje i izvršavanje javnih ugovora, prema kojima su izmjene takvih ugovora strogo propisane i države moraju uspostaviti učinkovit sustav kontrole nad njihovim izvršavanjem. Potrebno je ovdje spomenuti novu Direktivu 2014/23/EU od 26. veljače 2014. o dodjeli

17 Slično v. i Đerđa: „Ugovori o koncesiji prema svojoj prirodi su upravni ugovori, iz čega proizlazi i pravo nadzora koncedenta nad provođenjem ovoga ugovora, pravo jednostrane izmjene nekih odredbi ugovora, kao i pravo jednostranog opoziva koncesije“. Đerđa, D., „Koncesije“, Hrvatska pravna revija, br. 2/2015., str. 61 .

18 „Sukladno Zakonu o koncesijama postupak dodjele koncesije je upravni postupak koji započinje objavom "obavijesti o namjeri davanja koncesije" u Elektroničkom oglasniku javne nabave Republike Hrvatske, a završava izvršnošću "odluke o davanju koncesije" ili "odluke o poništenju postupka davanja koncesije”.“ Đerđa, D., „Opće pravno uređenje koncesija u Republici Hrvatskoj“, Hrvatska pravna revija, br. 6/2015., str. 41. Da je ugovor o koncesiji upravni ugovor i postupak dodjele koncesije upravni postupak, također smatraju Šikić i Staničić. V. u: Šikić, M., Staničić, F., „Pravna narav ugovora o koncesiji“ , Zbornik radova Pravnog fakulteta u Splitu, 48 (2011.), 2., str. 431-437.

19 O praksi Državne komisije za kontrolu postupaka javne nabave koja je zauzela stav da se kod odluke o odabiru u postupcima javne nabave radi o upravnom aktu (rješenju) v. infra.

20 U hrvatskoj pravnoj teoriji prevladava mišljenje da je ugovor o javnoj nabavi građanskopravni ugovor. V., primjerice, Koprić, I., Nikšić, S., „Upravni ugovori, područje primjene i primjena prava“, Zbornik susreta pravnika Opatija 48., str. 298., Pejaković, S., „Je li ugovor o javnoj nabavi upravni ugovor", Informator, br. 6171, str. 1-3. i Informator, br. 6172-6173, str. 13. i 14. Neki autori smatraju kako se radi o ugovoru koji ima obilježja upravnog ugovora, ali i obilježja građanskopravnih ugovora. V. Đerđa, D., Upravni ugovori u hrvatskom pravu, Informator br. 5809, str. 11, Crnković, M., „Upravni ugovori u posebnom zakonodavstvu Republike Hrvatske“, Hrvatska i komparativna javna uprava, 14 (2014.), br. 4., str. 1050.

${ }^{21}$ V. čl. 30., st. 2. Zakona o koncesijama i čl. 99., st. 1. i. 2. Zakona o javnoj nabavi. 
ugovora o koncesiji, ${ }^{22}$ a koju tek trebamo implementirati u hrvatsko pravo. ${ }^{23}$ Inače, može se reći kako je u EU-pravu prisutna tendencija jačanja prisutnosti intervencije EU u polju javnih ugovora budući da se zakonodavstvom EU uređuju ne samo više postupci dodjele javnih ugovora nego i izvršavanje javnih ugovora (izmjene, podugovaranje itd.). ${ }^{24}$

\section{VRSTE KONTROLE NAD SKLAPANJEM UPRAVNIH UGOVORA U HRVATSKOM PRAVU}

Kontrolu sklapanja upravnih ugovora možemo podijeliti na dva tipa: 1) kontrolu koja se provodi u upravnom postupku povodom žalbe na rješenje koje prethodi upravnom ugovoru (ex ante kontrola) i 2) kontrolu koja se provodi $\mathrm{u}$ sudskom postupku jednom kada je ugovor sklopljen (ex post kontrola).

Može se govoriti i o trećem tipu nadzora - upravnom nadzoru koji provode nadležna ministarstva (kod koncesija Ministarstvo financija, a kod javne nabave Ministarstvo gospodarstva) kao o obliku ex post kontrole. U nekim zakonima nalazimo i ex ante kontrolu u vidu potrebe pribavljanja suglasnosti za sklapanje ugovora ili njegove naknadne izmjene. ${ }^{25}$

\subsection{Kontrola u upravnom postupku}

Prije sklapanja upravnog ugovora, sukladno čl. 154., st. $1 .{ }^{26}$ ZUP-a, mora biti doneseno rješenje kojim se rješava upravna stvar. Prema tome, nakon donošenja rješenja kojim je meritorno riješena određena upravna stvar (primjerice, sukladno OPZ-u, rješenjem se utvrdila porezna obveza - porezni dug, pa je sukladno čl. 91.c OPZ-a porezni obveznik podnio prijedlog za sklapanje upravnog ugovora) može se pristupiti sklapanju upravnog ugovora. Naše pravo se, prema tome, opredijelilo za francuski koncept u kojemu sklapanju upravnog ugovora prethodi donošenje rješenja, za razliku od njemačkog koncepta u kojemu upravni ugovor zamjenjuje rješenje (v. §. 54. st. 2. VwVfG).

22 SL. L. 94/1 od 28. ožujka 2014.

23 Do 18. travnja 2016. godine. O potrebi implementacije ove Direktive pisao je Đerđa. V. u: Đerđa, D., „Pravno uređenje koncesija u pravu Europske unije“, Hrvatska pravna revija, br. 3/2015., str. 45-53.

${ }^{24}$ Mozzati, A., Afferni, G., „Recent developments in the European law of public contracts“, European Review of Contract Law, 4/2011., str. 553.

V. i Direktivu 2007/66/EC od 11. prosinca 2007. godine o poboljšavanju efikasnosti kontrolnih procedura glede dodjeljivanja javnih ugovora, SL. L. 335/31 od 20. prosinca 2007.

25 Tako Zakon o javno-privatnom partnerstvu (NN 78/12 i 152/14) propisuje da sve projekte javnoprivatnog partnerstva prethodno, da bi se mogao sklopiti ugovor, mora odobriti Agencija za investicije i konkurentnost, po prethodno pribavljenoj suglasnosti Ministarstva financija (čl. 9. u vezi s čl. 11.). Isti zakon propisuje da su izmjene i/ili dopune ugovora moguće samo uz suglasnost Agencije (čl. 19., st. 1 .).

26 ,(1) Javnopravno tijelo i stranka sklopit će upravni ugovor o izvršenju prava i obveza utvrđenih u rješenju kojim je riješena upravna stvar (podvukao autor), ako je zakonom propisano sklapanje takvog ugovora." 
Međutim, baš iz činjenice da je sustav javnih ugovora (pa i onih koji se, prema prevladavajućem mišljenju ne mogu smatrati upravnim ugovorima) postavljen na način da se prethodno donosi rješenje, a temeljem toga rješenja sklapa ugovor, proizašao je i najveći praktični problem u kontroli zakonitosti sklapanja upravnih ugovora.

Naime, protiv rješenja koje prethodi sklapanju ugovora može se, u pravilu, izjaviti žalba. Tako je Zakonom o koncesijama ${ }^{27}$ propisano da se protiv odluke o davanju koncesije, koja je upravni akt (rješenje), može izjaviti žalba Državnoj komisiji za kontrolu postupaka javne nabave (dalje u radu: DKOM), ${ }^{28} \mathrm{u}$ roku od 15 dana od dana dostave odluke o koncesiji svakom ponuditelju. Slično propisuje i Zakon o javnoj nabavi (dalje u radu: ZJN) ${ }^{29} \mathrm{~s}$ tim da su rokovi za žalbu protiv odluke o odabiru ${ }^{30}$ prema tom zakonu deset ${ }^{31}$ odnosno pet $^{32}$ dana. Ugovor se sklapa (odnosno kod javne nabave nastaje ugovor o javnoj nabavi odnosno okvirni sporazum $)^{33}$ po izvršnosti odluke o koncesiji odnosno odluke o odabiru, tj. po isteku roka za žalbu ukoliko žalba DKOM-u nije izjavljena, odnosno po završetku drugostupanjskog postupka pred DKOM-om.

Nakon što se žalbeni postupak okonča, rješenje postaje izvršno, pa se, opet u pravilu, mora ${ }^{34}$ sklopiti ugovor, odnosno ugovor nastaje izvršnošću odluke (kod javne nabave). ${ }^{35}$ Međutim, nije isključeno pravo osporavanja i drugostupanjskog

27 NN 143/12

28 „Državna komisija za kontrolu postupaka javne nabave nadležna je za rješavanje o žalbama u vezi s postupcima davanja koncesija“ - čl. 48., st. 1. Zakona o koncesijama.

29 NN 90/11, 83/13, 143/13 i 13/14.

30 Odluka o odabiru, sukladno praksi DKOM-a također predstavlja upravni akt (rješenje). V., tako, rješenje DKOM-a Klasa: UP/II-034-02/14-01/1235, Urbroj: 354-01/15-15 od 3. ožujka 2015. godine. Navedeno rješenje opširno je analizirao Šprajc, iz čije analize izdvajam: „DKOM je u takvoj situaciji prihvatio nadležnost te proveo postupak u kojem je najprije zaključio da je osporena odluka o odabiru akt koji udovoljava normativnim odlikama upravnog akta, pa je nakon toga donio odluku o odbijanju prijedloga za oglašivanje ništavim navedenog akta. Sama okolnost da je prijedlog odbijen, a ne odbačen, ukazuje na implicitno izražen stav DKOM-a o odlučivanju u meritumu stvari, što je moguće tek ako se prethodno usvoji shvaćanje o pravnoj naravi odluke o odabiru kao upravnog akta. Istini za volju, obrazloženje tog segmenta Rješenja 0403 je oskudno, no i takvo pruža osnove za netom iznesene zaključke. Naime, DKOM je citirajući odredbu ZUP-a o razlozima oglašivanja rješenja ništavim, zaključio da “... vezano za zahtjev kojim je traženo da se odluka o odabiru br... od 5. prosinca 2014. godine oglasi ništavom valja naglasiti da je isti neosnovan budući da nisu ispunjene pretpostavke propisane člankom 128. stavak 1 . Zakona o općem upravnom postupku". Citirano mjesto, dakle, jasno ukazuje na stav koji je ovo tijelo već prije iskazivalo kada je, u drukčijoj postupovnoj konstelaciji, ali explicite, analiziralo pravnu narav odluke o odabiru.“ V. u: Šprajc, I., „O važnosti jednog rješenja Državne komisije za kontrolu postupaka javne nabave", Hrvatska pravna revija, br. 5/2015., str. 51.

31 U otvorenom postupku javne nabave velike vrijednosti, u ograničenom i pregovaračkom postupku javne nabave s prethodnom objavom i natjecateljskom dijalogu velike vrijednosti.

32 U otvorenom postupku javne nabave male vrijednosti i postupcima nabave male vrijednosti.

33 Čl. 99., st. 2. ZJN-a. Ukoliko je potrebna suglasnost mjerodavnog tijela, ugovor odnosno sporazum nastaju trenutkom pribavljanja suglasnosti (čl. 99., st. 3. ZJN-a).

34 „Davatelj koncesije mora odabranom najpovoljnijem ponuditelju, ponuditi sklapanje ugovora o koncesiji najkasnije u roku od 10 dana od isteka razdoblja mirovanja iz stavka 1. ovoga članka, odnosno 10 dana od dana kada je odluka o davanju koncesije postala izvršna“ - čl. 30., st. 3. Zakona o koncesijama.

35 Čl. 99., st. 2. ZJNa-a. 
rješenja kojim je, primjerice, žalba protiv rješenja koje je prethodilo upravnom ugovoru odbijena, u upravnom sporu, što se često i događa. Prema tome, javnopravno tijelo i stranka mogu sklopiti ugovor, odnosno javnopravno tijelo mora stranci ponuditi sklapanje upravnog ugovora, unatoč činjenici da se o rješenju temeljem kojega se sklapa upravni ugovor vodi ili se može voditi upravni spor.

Naravno, činjenica da se mogao voditi ili da se vodio upravni spor neće imati nikakvih posljedica po sklopljeni ugovor ukoliko sud eventualnu tužbu protiv rješenja odbaci ili odbije, ali može imati velikih posljedica ukoliko sud tužbu uvaži i poništi rješenje temeljem kojega je sklopljen ugovor. U našem se pravu postavljalo pitanje važenja ugovora koji je tako sklopljen. U slučaju da se radi o „čistom“ upravnom ugovoru, odgovor je jasan. Takav ugovor bi morao prestati proizvoditi pravne učinke, budući da ugovor mora biti u skladu s izrekom rješenja koje mu je prethodilo. Kako više nema rješenja, više ne bi mogao opstati niti upravni ugovor. Naime, upravni ugovor mora biti u skladu s izrekom rješenja koje mu je prethodilo. Kako više nema rješenja, ugovor ne može biti u skladu s izrekom rješenja, pa je, shodno tome, i u skladu s čl. 151., st. 1. ZUP-a, ništetan.

Međutim, situacija nije, odnosno ne može se smatrati jednostavnom kada je po sklapanju ugovora poništen upravni akt koji je prethodio sklapanju ugovora koji se, prema prevladavajućem stajalištu, ne mogu smatrati upravnim ugovorima jer u zakonu koji ih uređuje ne stoji da se radi o upravnim ugovorima ili je njihova pravna priroda sporna. Posebno je ovaj problem bio aktualan kod ugovora o koncesiji, pa je zato, kada je donesen novi Zakon o koncesijama 2012. godine, posebno propisano $^{36}$ da ugovor o koncesiji prestaje, po sili zakona, ukoliko dođe do poništavanja, ukidanja ili oglašivanja ništavom odluke o koncesiji kojom je koncesija dodijeljena i temeljem koje je ugovor o koncesiji sklopljen. Naime, prije 2012. godine smatralo se kako poništenje odluke o koncesiji nema utjecaja na sklopljeni ugovor o koncesiji.

Poseban je problem prisutan u slučaju da je ugovor koji se temeljio na poništenom rješenju izvršen, odnosno konzumiran. Naime, teoretski, kada se poništi rješenje koje je prethodilo sklapanju ugovora, ugovor bi trebao prestati djelovati, upravna stvar bi se trebala vratiti u stanje prije donošenja rješenja i trebalo bi se donijeti novo rješenje koje bi trebalo biti temelj za novi ugovor. ${ }^{37}$ Međutim, u brojnim slučajevima donošenje novog rješenja bilo bi besmisleno, ili čak i nemoguće po prirodi stvari. Ovo se posebno odnosi na ugovore o javnoj nabavi ili javnim radovima.

Naime, upravni sporovi traju određeno vrijeme, a primjerice, ugovor o javnoj nabavi za nabavu kompjuterske opreme bit će izvršen, u pravilu, brzo nakon sklapanja, tj. puno prije nego li se upravni spor okonča. U ovakvoj situaciji,

36 Čl. 45. Zakona o koncesijama.

37 Ovo logično proizlazi iz činjenice da ,,u hijerarhiji pravnih akata i njihove pravne snage odluka o koncesiji, kao akt imperativne naravi, ima veću pravnu snagu u odnosu na odredbe ugovora o koncesiji koje s njima moraju biti u skladu.“V. u: Đerđa, D., „Koncesije“, op. cit., str. 61. 
donošenje novog akta o odabiru nema smisla, jer je predmet nabave već nabavljen i plaćen, a ugovor o javnoj nabavi konzumiran i izvršen, pa javni naručitelj ne može ponovno pokrenuti postupak javne nabave za isti predmet nabave. Trećoj strani, koja je uspjela u osporavanju akta o odabiru preostaje jedino tužba za naknadu štete, a sam ugovor o javnoj nabavi ne može osporavati. Ovakva situacija može rezultirati činjenicom da naručitelj odnosno davatelj koncesije, tj. javnopravno tijelo koje sklapa javni ugovor mora istu stvar platiti dva puta, odnosno da neće biti pozitivnog financijskog efekta od sklapanja javnog ugovora zbog obveze plaćanja naknade štete.

Praktično rješenje ovog problema postoji u ZUS-u, i to u formi privremenih mjera. ${ }^{38}$ Naime, sud je ovlašten izdati privremenu mjeru, temeljem čl. 47. ZUS-a, ako je to nužno kako bi se izbjegla teška i nepopravljiva šteta. Prema tome, ukoliko bi treća osoba ${ }^{39}$ osporavala zakonitost rješenja koje prethodi sklapanju ugovora, i zatražila od suda privremenu mjeru, sud bi bio ovlašten zabraniti javnopravnom tijelu sklapanje upravnog ugovora do pravomoćnosti presude. Na taj bi se način izbjegli mnogobrojni problemi koji nastaju u praksi, ali naši upravni sudovi nisu prepoznali institut privremenih mjera kao koristan alat, što bi se, prema mojem mišljenju, trebalo promijeniti.

\section{1. 1. Izravna tužba protiv javnog ugovora}

Ako se radi o ,čistom“ upravnom ugovoru, neuspjeli žalitelj bi mogao, sukladno Zakonu o upravnim sporovima (dalje u radu: ZUS), ${ }^{40}$ podnijeti tužbu izravno protiv sklopljenog ugovora, ,preskačući“ tužbu protiv rješenja kojim mu je odbijena žalba, tužbom osporavajući zakonitost sklapanja upravnog ugovora. U ovom bi slučaju sud morao provjeriti i zakonitost rješenja koje je prethodilo sklapanju ugovora, pa bi se, u osnovi, vodio spor o zakonitosti rješenja kojeg bi slijedio spor o zakonitosti sklapanja upravnog ugovora. Naime, ZUS propisuje čl. 3., st. 1., t. 4. kako je jedan od predmeta upravnog spora i „ocjena zakonitosti sklapanja, raskidanja i izvršavanja upravnog ugovora“. Dodatno, tužbenim zahtjevom se može postići, sukladno čl. 22., st. 2., t. 4. ZUS-a „oglašivanje ništetnim upravnog ugovora ili izvršavanje obveze iz upravnog ugovora“. Iz navedenoga jasno slijedi da se upravni ugovor može osporavati izravno, bez potrebe da se prethodno $u$ upravnom sporu ospori rješenje koje mu je prethodilo. Ipak, potrebno je razjasniti mogući problem koji bi se u izravnom pobijanju upravnog ugovora ipak mogao, u praksi, pojaviti. Naime, moglo bi se tvrditi kako je tužba podnesena, a na raspolaganju je bio upravni spor protiv rješenja kojim je odbijena žalba protiv odluke koja je prethodila sklapanju ugovora, pa nije ispunjen uvjet iz ZUS-a o

38 O učinku privremenih mjera u upravnom sporu v. u: Staničić, F., „Učinak vođenja upravnog spora na izvršnost upravnih odluka: privremene mjere i odgodni učinak tužbe“, Zbornik radova Pravnog fakulteta u Splitu, vol 52, br. 1., 2014., str. 161-165.

39 Dakako, ona koja je prethodno sudjelovala u postupku donošenja rješenja temeljem kojega je sklopljen ugovor, nap. a.

40 NN 20/10, 143/12, 152/14. 
korištenju svih dostupnih ${ }^{41}$ pravnih sredstava. Međutim, smatram kako tome ne bi bio slučaj jer se radi o dva odvojena akta. Jedno je rješenje, protiv kojega se može pokrenuti upravni spor, a odvojeni je akt upravni ugovor, zakonitost sklapanja kojega se može, sukladno odredbama ZUS-a, osporavati u upravnom sporu. Zauzimanje suprotnog stava značilo bi da odredbe ZUS-a koje uređuju tužbu protiv upravnog ugovora ili nemaju smisla, ili su na raspolaganju samo strankama upravnog ugovora, što nije u skladu sa samom prirodom upravnog ugovora.

Zanimljiva bi bila situacija u kojoj bi tužitelj ustao s tužbom pred upravnim sudom izravno protiv ugovora za koji je, inače, za sporove među strankama, propisana nadležnost trgovačkog suda ili za koje nadležnost nije izrijekom propisana. Kako bi se upravni sud postavio prema takvoj tužbi? Bi li zauzeo stav da, zato što nije izrijekom propisano da se radi o upravnom ugovoru ili zato što je propisana nadležnost trgovačkog suda, za sporove koji nastanu među strankama ugovora nije nadležan? Ili bi prihvatio nadležnost i riješio upravni spor? Osobno smatram da bi upravni sud bio nadležan i da bi trebao riješiti upravni spor. Naime, i u slučajevima kada je propisana nadležnost trgovačkog suda, bilo bi pogrešno automatski pretpostaviti kako je stvarna nadležnost trgovačkih sudova uspostavljena, primjerice, za sve sporove oko ugovora o koncesiji, neovisno o tome tko bi se u eventualno pokrenutom sporu našao kao stranka. Naime, točno je kako čl. 49. Zakona o koncesijama uspostavlja stvarnu nadležnost trgovačkih sudova, ali, ako ispravno čitamo navedenu zakonsku odredbu, onda vidimo kako je jedino nesporno da je trgovački sud stvarno nadležan za sporove koji u pogledu ugovora o koncesiji nastanu među strankama ugovora o koncesiji, a i to samo ukoliko nisu ugovorile arbitražu, sukladno čl. 49., st. 1. Zakona o koncesijama. Što, međutim, ukoliko ništetnost ugovora zahtijeva treća osoba? I to u upravnom sporu? Budući da smatram da ugovor o koncesiji zadovoljava sve uvjete kako bi se mogao smatrati upravnim ugovorom, to sam mišljenja kako bi upravni sud takvu tužbu morao uzeti u razmatranje.

\subsection{Kontrola putem sudova}

Kada govorimo o sudskoj kontroli samog ugovora, onda imamo dvije situacije. Za upravne ugovore, odnosno za kontrolu zakonitosti njihova sklapanja, izvršavanja i raskida nadležni su, temeljem čl. 12. i 22. ZUS-a, prvostupanjski upravni sudovi. Tužitelj može u tužbenom zahtjevu tražiti oglašivanje ništetnim upravnog ugovora ili izvršavanje obveze iz upravnog ugovora, a u upravnom sporu se može osporavati i zakonitost raskida upravnog ugovora. Primjerice, ukoliko je za sklapanje upravnog ugovora između Porezne uprave i poreznog dužnika bila potrebna suglasnost treće osobe, a te suglasnosti nije bilo, ta treća osoba ima, prema mojem mišljenju, pravo tužbom tražiti od upravnog suda da oglasi takav upravni ugovor ništetnim.

${ }_{41}$ Čl. 30., st. 1., t. 3. ZUS-a. 
S druge strane, za sporove glede ugovora za koje nije izrijekom propisano da su upravni ugovori ne možemo sa sigurnošću precizirati nadležnost za sporove koji iz njih proizađu. Naime, jasno je da će trgovački sud biti nadležan za spor koji nastane između stranaka ugovora o koncesiji zbog izričite zakonske odredbe koja to propisuje, ali ostaje pitanje moguće nadležnosti upravnih sudova po zaprimanju tužbi trećih osoba koje su sudjelovale u postupku dodjele koncesije i koje bi osporavale zakonitost ugovora ili, primjerice, njegovih izmjena. Ono što je nepobitno jest da je uvijek potrebno postojanje pravnog interesa. Mišljenja sam da navedeno vrijedi i za javnu nabavu.

Jasno je da je situacija u kojoj o istoj stvari postoje dvije odvojene sudske nadležnosti: upravnosudska u kojoj se ispituje zakonitost rješenja koje prethodi sklapanju ugovora, i redovnosudska u kojoj se rješavaju sporovi koji proizađu iz samog ugovora - nije dobra. Naime, moglo bi se tvrditi da onda treće osobe koje su sudjelovale u postupku koji je prethodio sklapanju ugovora nemaju pravo na osporavanje samog ugovora, čak i ako bi došlo do izmjena tog ugovora zbog kojih on više ne bi bio u skladu s odlukom koja mu je prethodila. Jer, ako se radi o građanskopravnom ugovoru, jedino su stranke tog ugovora ovlaštene na njegovo osporavanje, osim ako uzmemo u obzir odredbe ZOO-a. I u tom slučaju stranka koja traži utvrđivanje ništetnosti mora dokazati svoj pravni interes, pri čemu bi sud mogao utvrditi kako isti ne postoji. Međutim, smatram kako bi, primjerice, bilo osnove da upravni sud prihvati nadležnost rješavanja tužbenog zahtjeva kojim bi treća osoba tražila proglašenje ugovora ništetnim temeljem odredaba ${ }^{42} \mathrm{ZUP}-\mathrm{a}$.

\section{3. Kontrola putem upravnog nadzora}

Određeni ugovori, odnosno njihovo izvršavanje predmet su i kontrole u obliku upravnog nadzora, što se posebno odnosi na ugovore o koncesijama. Naime, sukladno Zakonu o koncesijama, Ministarstvo financija ovlašteno je provoditi opsežni nadzor nad izvršavanjem ugovora o koncesiji, ali primarno u svrhu osiguravanja naplate naknade za koncesiju. ${ }^{43}$ Ipak, davatelj koncesije može zatražiti od Ministarstva financija provođenje nadzora nad koncesionarom i glede izvršavanja drugih obveza koje proizlaze iz ugovora o koncesiji.

Prema odredbama ZJN-a, Ministarstvo gospodarstva, u svrhu sprečavanja i otklanjanja nepravilnosti koje mogu nastati ili su nastale kao posljedica povrede toga zakona i podzakonskih propisa u polju javne nabave provodi nadzor. Isto tako,

42 ,(1) Upravni ugovor je ništetan ako je protivan rješenju radi izvršenja kojeg je sklopljen. odnose.

(2) Upravni ugovor je ništetan i iz razloga ništetnosti propisanih zakonom koji uređuje obvezne

(3) Upravni ugovor je ništetan i kad je ništetan dio toga ugovora, osim ako bi ugovor proizvodio pravne učinke i bez tog dijela.

(4) Ništetnost upravnog ugovora utvrđuje sud nadležan za upravne sporove na temelju tužbe stranke ili javnopravnog tijela.

(5) Ništetan upravni ugovor ne proizvodi pravne posljedice" - čl. 151. ZUP-a.

43 V. čl. 52-54. Zakona o koncesijama. 
Ministarstvo gospodarstva može od svih naručitelja zatražiti svu dokumentaciju glede postupaka i ugovora o javnoj nabavi. ${ }^{44}$

Dodatno, potrebno je spomenuti i nadzor što ga, kod javne nabave, ali zamisliva je slična situacija i kod ostalih javnih ugovora, provodi Agencija za zaštitu tržišnog natjecanja (dalje u radu: AZTN) koja, sukladno čl. 9. Zakona o zaštiti tržišnog natjecanja (dalje u radu: ZZTN) ${ }^{45}$ utvrđuje postojanje zabranjenih sporazuma iz čl. 8. navedenog zakona. Naime, moguće je i posve zamislivo da natjecatelji u postupcima javne nabave postignu tajni dogovor o raspodjeli poslova, što bi, sukladno čl. 8. ZZTN-a predstavljalo zabranjeni sporazum, jer bi se dijelila tržišta ili izvori nabave, a sukladno čl. 8., st. 1., t. 3. ZZTN-a. U tom slučaju AZTN rješenjem utvrđuje postojanje zabranjenog sporazuma, sudionike zabranjenog sporazuma, vrstu sporazuma, robe/usluge na koje sporazum ima ili može imati učinak, zemljopisno područje na kojem sporazum ima učinak, trajanje sporazuma, cilj sporazuma i način provođenja sporazuma. Osim toga, istim rješenjem AZTN određuje mjere, uvjete i rokove za otklanjanje štetnih učinaka zabranjenog sporazuma te izriče upravno-kaznene mjere propisane čl. $61{ }^{46} \mathrm{ZZTN}-\mathrm{a}$. Protiv toga rješenja moguća je tužba Visokom upravnom sudu Republike Hrvatske sukladno čl. 67. ZZTN-a.

\section{MOGUĆA RJEŠENJA DETEKTIRANIH PROBLEMA}

Kako sam već naveo, najveći problem pri kontroli sklapanja upravnih ugovora proizlazi iz činjenice da je ta kontrola podijeljena u dva dijela koji međusobno nemaju čvrste poveznice. Naime, protiv rješenja koje prethodi sklapanju ugovora moguća je žalba, u dva najviše spominjana slučaja (koncesije i javna nabava) DKOM-u, pa ću taj primjer koristiti i dalje. Stranka koja je nezadovoljna donesenim rješenjem (odlukom o koncesiji odnosno odlukom o odabiru) ima pravo u zakonom propisanim rokovima izjaviti žalbu DKOM-u. U slučaju da DKOM žalbu uvaži, stvar se vraća na početak i ponovno se provodi postupak odabira. Međutim, ukoliko DKOM žalbu odbije ili odbaci, sklapa se ugovor o koncesiji odnosno ugovor o javnoj nabavi. Međutim, stranka koja nije uspjela u žalbi ima mogućnost pokretanja upravnog spora protiv rješenja DKOM-a, i nerijetko stranke

44 V. čl. 179. i 180. ZJN-a.

45 NN 79/09 i 80/13.

46 „Upravno-kaznenom mjerom u iznosu do najviše $10 \%$ vrijednosti ukupnoga prihoda koji je poduzetnik ostvario u posljednjoj godini za koju postoje zaključena godišnja financijska izvješća, kaznit će se poduzetnik koji:

1. sklopi zabranjeni sporazum ili na koji drugi način sudjeluje u sporazumu kojim je narušeno tržišno natjecanje, na način opisan odredbom članka 8. ovoga Zakona i članka 101. UFEU-a,

2. zlouporabi vladajući položaj na način opisan odredbom članka 13. ovoga Zakona i članka 102. UFEU-a, Zakona,

3. sudjeluje u provedbi zabranjene koncentracije poduzetnika, opisanoj odredbom članka 16. ovoga

4. ne postupi po rješenju Agencije kojim se određuju mjere za uspostavu tržišnog natjecanja ili određuju privremene mjere (članak 58., stavak 1., točke 1. do 11.).“ 
to pravo koriste. Upravni sudovi mogu poništiti rješenje DKOM-a i stvar vratiti na početak. Međutim, kako tužba u pravilu, sukladno čl. 26. ZUS-a nema odgodni učinak, ugovor se sklopi, a kako sam već i naveo, često i konzumira odnosno izvrši prije nego li upravni sud donese svoju odluku. Osim toga, ukoliko prihvatimo stav da su i drugi ugovori osim onoga prema OPZ-u upravni ugovori, onda se ti ugovori mogu osporavati sukladno odredbama ZUS-a pred upravnim sudovima, iako je propisana i nadležnost redovnog sudstva. Ovako stvoreni dualitet sudske nadležnosti nikako nije dobar i trebalo bi ga ukloniti iz našeg pravnog sustava. Ovakva situacija posljedica je našeg „lutanja“ između dvaju modela, francuskog i njemačkog, gdje smo iz francuskog modela preuzeli uređenje upravnih ugovora na način da ugovoru prethodi rješenje i da je za sporove nadležan upravni sud, ali smo u posebnom zakonodavstvu izmiješali javno i privatno pravo i uspostavili sudsku nadležnost redovnih sudova za sporove koji proizlaze iz ugovora koji bi se mogli (morali) smatrati upravnim ugovorima.

U cilju rješavanja ovih problema predložio bih dva moguća rješenja. Oba rješenja uključuju u sebi i neophodnu potrebu da se u našem pravu uspostavi konzistentni sustav sklapanja i izvršavanja upravnih ugovora (odnosno javnih ugovora) kojega ćemo se onda, jednom kada ga uspostavimo, čvrsto držati (i) u posebnom zakonodavstvu. Mora postojati set pravila koja će vrijediti za svaki ugovor jednako, ukoliko ugovor zadovoljava određene uvjete koje sam naveo supra. Naš sustav, u kojemu je u upravnoj fazi dodjele ugovora nadležno upravno sudstvo, a u fazi izvršavanja javnih ugovora redovno sudstvo, nije nepoznat u Europi, takav sustav ima Italija, ${ }^{47}$ ali smatram da je jasno da kod nas takav sustav ne funkcionira i da ga je potrebno ili modificirati ili potpuno promijeniti.

Prvo moguće rješenje bilo bi da se za ugovore o koncesiji i ugovore o javnoj nabavi te ostale javne ugovore propiše nadležnost isključivo upravnih sudova, odnosno da se u našem pravnom sustavu odlučimo za francuski model javnih ugovora uz obvezu sudova da prilikom rješavanja tužbi koriste privremene mjere. Bilo bi neophodno jasnije normirati i detaljnije propisati postupak sklapanja upravnih (javnih) ugovora u ZUP-u, kao i definirati takve ugovore, kako se u budućnosti ne bi ponovno pojavile dvojbe glede pravne prirode određenih ugovora. Prema tome, ukoliko bi se RH odlučila za prvo rješenje, neophodna je izmjena ZUP-a, kao i posebnog zakonodavstva te isključenje nadležnosti redovnih sudova za sporove koji proizlaze iz sklapanja, izvršavanja i raskida javnih ugovora.

Kao drugo moguće rješenje ovakve situacije, barem za dva tipa ugovora kojih se u radu najviše dotičem, bilo bi vrijedno promotriti njemačko rješenje. Naime, njemački Gesetz gegen Wettbewerbsbeschränkungen (dalje u radu: $\mathrm{GWB})^{48}$ uređuje, u svom dijelu IV. dodjelu javnih ugovora (Vergabe öffentlicher

47 Comba, M. E., op. cit., str. 307.

48 Zakon o zaštiti tržišnog natjecanja, BGBI I 2546. 
Aufträge). ${ }^{49} \mathrm{U}$ navedenom zakonu propisuju se tijela koja moraju provoditi posebne postupke prilikom sklapanja ugovora (§. 98. GWB-a), a propisano je i u kojim se područjima ${ }^{50}$ mora provoditi posebni postupak pri sklapanju i dodjeli javnih ugovora te su definirani javni ugovori (\$. 99. GWB-a). GWB-om su uspostavljena posebna tijela - tribunali koja rješavaju sporove koji mogu proizaći iz postupka sklapanja javnih ugovora. Postoje tribunali na saveznoj razini i na razini zemalja ( $\$$. 104. GWB-a) te savezni tribunali rješavaju žalbe protiv ugovora koji se sklapaju na saveznoj razini, a tribunali zemalja na lokalnoj razini. Radi se o neovisnim tijelima koja rješavaju u vijećima i čiji se članovi imenuju na mandat od pet godina. U postupku su dužni po službenoj dužnosti (ex officio) utvrditi činjenično stanje uz obvezu održavanja jedne usmene rasprave. Odluka se mora donijeti u roku od pet tjedana i predstavlja upravni akt (§. 114. st. 3. GWB-a). Protiv odluke tribunala, bilo saveznog, bilo zemaljskog, dopuštena je, u roku od dva tjedna od dostave odluke stranci, tužba žalbenom sudu (Oberlandesgericht $)^{51}$ koja ima suspenzivni učinak ( $\$$. 118. GWB-a), a tužbu može izjaviti svatko tko je sudjelovao u postupku pred tribunalom (§. 116. st. 1. GWB-a). Iako tužba ima suspenzivni učinak, sud može, ocjenjujući šanse uspjeha tužbe, ipak dopustiti nastavak postupka sklapanja ugovora. Dodatno, sud ima pravo, ukoliko procijeni da je u javnom interesu brzi završetak postupka dodjele javnog ugovora, a negativne su posljedice nesklapanja ugovora do rješavanja tužbe tolike da pretežu nad zaštitom prava pojedinca, dopustiti sklapanje ugovora. Sud je dužan tužbu riješiti bez odgađanja, a najkasnije u roku od pet tjedana od njenog zaprimanja te protiv njegove odluke nije dopuštena žalba (§. 121. st. 3. i 4. GWB-a). Pri odlučivanju o tužbi sud ima široke ovlasti - može sam meritorno riješiti stvar ili je vratiti na ponovno odlučivanje tribunalu. U slučaju kasnijih sporova glede izvršavanja ugovora također je nadležan redovni sud.

Kao što vidimo, njemačko rješenje je takvo da osigurava relativno brzo rješenje eventualnog spora koji bi se pojavio glede dodjele javnog ugovora. Iako tribunali odlučuju, u žalbenom postupku koji je upravni i donose upravni akt o žalbi žalitelja, protiv njihove odluke rješava isključivo redovni sud čija je odluka konačna. I sud mora riješiti u vrlo kratkom roku, tako da cjelokupni žalbeni i sudski postupak mora završiti u maksimalno 98 dana.

Pogledajmo, sada, je li ovaj sustav primjenjiv u našem pravu. Prvo, potrebno je reći zadovoljava li DKOM, prema sadašnjem pravnom uređenju, uvjet da bi se smatrao neovisnim tijelom koje rješava žalbe protiv javnih ugovora. Sukladno

49 Dodatno, dodjelu javnih ugovora, posebice u polju javne nabave, u njemačkom pravu uređuje Verordnung über die Vergabe öffentlicher Aufträge (Vergabeverordnung-VgV, BGBl. I S. 169, BGBl. I S. 1474.) koja uređuje polja na koja se primjenjuje te vrijednosti nabave na koju se ona primjenjuje.

50 Javna nabava, javne usluge i javni radovi. V. §. 97. st. 1. GWB-a.

51 Na tim, redovnim, sudovima ustrojeni su posebni prizivni senati (Vergabesenate) koji su specijalizirani za rješavanje takvih sporova. V. i u: Burgi, M., Public procurement law in the Federal Republic of Germany, Annual report - 2012 - Germany, dostupno na:

http://www.ius-publicum.com/repository/uploads/09_02_2012_9_43_Burgi.pdf [5. 10. 2015.] 
Zakonu o Državnoj komisiji za kontrolu postupaka javne nabave, ${ }^{52}$ DKOM je samostalno i neovisno državno tijelo nadležno za rješavanje o žalbama u vezi s postupcima javne nabave, postupcima davanja koncesija i postupcima odabira privatnog partnera u projektima javno-privatnog partnerstva (čl. 3., st. 1.) koje za svoj rad odgovara Hrvatskom saboru (čl. 4., st. 1.). Prema tome, ukoliko pogledamo zakonodavni okvir, DKOM zadovoljava uvjete prikazane u njemačkom modelu. DKOM je nadležan za rješavanje žalbi u vezi s postupcima javne nabave, postupcima davanja koncesija i postupcima odabira privatnog partnera u projektima javno-privatnog partnerstva, ali se protiv njegovih odluka može pokrenuti upravni spor. Prema tome, sudsku zaštitu protiv odluka DKOM-a pruža upravno sudstvo, a ne redovno. Unatoč tome, za određene sporove iz istih područja nadležni su i redovni sudovi.

Ukoliko bi se RH odlučila na primjenu njemačkog modela, bilo bi potrebno isključiti upravni spor protiv odluka DKOM-a i propisati nadležnost redovnih sudova za sporove koji bi proizašli glede sklapanja, ali i izvršavanja te raskida ugovora. Pravo na tužbu morale bi imati sve stranke koje su sudjelovale u postupku koji je prethodio sklapanju ugovora, bilo glede osporavanja zakonitosti sklopljenog ugovora, bilo glede kasnijih izmjena ugovora ili njegova (ne) izvršavanja. Jednako kao i u njemačkom pravu, morali bi biti propisani relativno kratki rokovi za rješavanje, bilo DKOM-a, bilo suda. Mišljenja sam kako bi rok od do 30 dana i za DKOM i za sud bio primjeren, ali isto tako predlažem, poučen dosadašnjim iskustvima s propisivanjem da je neki spor „hitan“, uvođenje sankcija za nepridržavanje navedenih rokova, i to novčanih sankcija za predsjednika DKOM-a i vijeće DKOM-a koje je trebalo riješiti predmet, ${ }^{53}$ kao i za predsjednika suda i sudsko vijeće koje je trebalo riješiti spor. ${ }^{54}$

Smatram i kako bi bilo potrebno, radi povećanja kvalitete nadzora, u slučaju da se prihvati ovo rješenje, uvesti specijalizaciju, pa da ovakve sporove rješava jedan sud u državi, primjerice Županijski sud u Zagrebu kao najveći i najekipiraniji. Tužba bi morala imati suspenzivni učinak, ali, kao i u njemačkom pravu, sud bi

52 NN 18/13, 127/13, 74/14.

53 Po uzoru na odredbe čl. 13., st. 5., 6. i. 7. Zakona o strateškim investicijskim projektima Republike Hrvatske (NN 133/13 i 152/14) koje propisuju da nepostupanje u rokovima propisanima tim Zakonom predstavlja tešku povredu službene dužnosti službene osobe koja provodi postupak, dok se javnopravno tijelo kažnjava novčanom kaznom od 5.000,00 kuna po danu zakašnjenja.

54 Iako ova ideja na prvi pogled izgleda revolucionarna, nekome možda i neprimjerena, uporište za svoj stav nalazim u Zakonu o državnom sudbenom vijeću (NN 116/10, 57/11, 130/11, 13/13, 28/13, 82/15). Naime, sukladno tome Zakonu, Državno sudbeno vijeće (dalje u radu: DSV) nadležno je za provođenje stegovnih postupaka prema sucima i odlučivanje o njihovoj stegovnoj odgovornosti (čl. 42., st. 1., al. 5.). Sukladno čl. 62., st. 1. ovoga Zakona, sudac odgovara za počinjena stegovna djela. Među stegovna djela spada i neuredno obnašanje sudačke dužnosti (čl. 62., st. 1., 2., al. 1.). Smatram da se u slučaju prihvaćanja novog modela može, posebnim zakonodavstvom, propisati da nerješavanje tužbi u zakonom propisanom roku predstavlja neuredno obnašanje sudačke dužnosti i da je DSV dužan pokrenuti stegovne postupke, posebno s obzirom na čl. 62., st. 3., al. 4. ovoga Zakona. DSV u stegovnom postupku može sucu, između ostalog, odrediti novčanu kaznu do jedne trećine plaće, na najduže razdoblje od dvanaest mjeseci (čl. 63., st. 1.). 
imao pravo dozvoliti sklapanje ugovora ako bi procijenio da bi šteta koja bi mogla nastati bila značajnija od moguće povrede prava pojedinca.

\section{ZAKLJUČAK}

Općenito, koncepcija u kojoj bi ugovori kojima prethodi donošenje upravnog akta, a to su i ugovori o javnoj nabavi i ugovori o koncesijama, spadali u građanskopravne ugovore, unosi velike probleme u mogućnost adekvatne kontrole nad njima. Vidimo, međutim, kako je kontrola koja se provodi u upravnom postupku neadekvatna zbog činjenice da osporavanje samog akta koji prethodi sklapanju ugovora može trajati, i u pravilu traje, dugo nakon sklapanja samog ugovora, pa se postavlja pitanje njenog smisla, osim očite potrebe da se trećoj osobi nadoknadi šteta koja joj je nastala jer je ugovor sklopljen protivno zakonu.

Zauzimam se za jasno definiranje ,javnih ugovora“, odnosno njihovo pozicioniranje $\mathrm{u}$ javno pravo te za primjenu pravila javnog prava na takve ugovore. Mišljenja sam kako je potrebno izmijeniti i dopuniti ZUP na način koji bi omogućio jednoobrazno sklapanje i kontrolu zakonitosti sklapanja, izvršavanja i raskida svih javnih ugovora. ZUP bi se morao primjenivati na postupke sklapanja svih javnih ugovora bez iznimke, dakle zalažem se za „čisti“ francuski model.

Smatram kako treba proširiti mogućnost kontrole sklapanja javnih ugovora na način da se izrijekom propiše kako ga mogu osporavati sve osobe koje su sudjelovale u postupku koji je prethodio njihovu sklapanju. ${ }^{55}$ Kako bi se to osiguralo, potrebno je propisati i obvezu dostave javnih ugovora, kao i njihovih budućih izmjena, svima koji su u postupku sudjelovali, kako bi bili u mogućnosti kontrolirati zakonitost samog sklapanja ugovora - je li u skladu s aktom koji mu je prethodio, kao i zakonitost izmjena u ugovoru, tj. jesu li izmjene načinjene u skladu sa zakonom. Na ovaj način bi se osigurala maksimalna kontrola nad zakonitosti sklapanja i izvršavanja javnih ugovora. Oni koji su sudjelovali u postupku su u potencijalno idealnoj situaciji da procijene eventualne nezakonitosti i nepravilnosti u sklapanju i daljnjem izvršavanju ugovora. ${ }^{56}$

Osim toga, smatram kako je neophodno unaprijediti sustav pravne zaštite protiv rješenja koje prethodi sklapanju upravnog ugovora, a koji omogućava da se ugovor sklopi unatoč tome što se protiv rješenja vodi upravni spor. Ovo kasnije dovodi do brojnih negativnih posljedica. Takva se situacija može popraviti korištenjem privremenih mjera, na način da sud zabrani sklapanje upravnog ugovora. Dakako, ne uvijek i na svaki prijedlog tužitelja. Sud bi morao, prilikom odlučivanja o privremenoj mjeri, provesti, na određeni način, ,preliminarni“ postupak i utvrditi je li vjerojatno da je rješenje koje se osporava nezakonito, po

55 Tako i Racca, G. M., Cavallo Perin, R., „Material Amendments of Public Contracts during their Terms“, European Procurement \& Public Private Partnership Law Review, 4/2013, str. 293 (279-293).

56 Ibid. 
uzoru na rješenje iz ZUP-a kada se prije odlučivanja o obnovi postupka ispituje vjerojatnost okolnosti ${ }^{57}$ koje stranka navodi.

Drugo bi moguće rješenje ovog problema bilo zabrana sklapanja ugovora do okončanja spora, ali takvo rješenje bi, ponajprije, pogodovalo zlonamjernim tužbama, posebno u sustavu u kojem u upravnom sporu svatko snosi svoje troškove. Osim toga, zbog relativne sporosti sudstva, takvo bi rješenje prouzročilo probleme u onim situacijama u kojima je u postupku sve bilo u skladu sa zakonom, ali je sklapanje ugovora bilo neopravdano odgođeno do kraja spora. Zbog navedenoga se priklanjam prvom rješenju i naglašavam važnost privremenih mjera, instituta koji je neopravdano posve zanemaren u našoj upravnosudskoj praksi.

Posebno rješenje predstavljala bi primjena njemačkog modela koji zahtijeva jačanje uloge DKOM-a i širenje njegovih ovlasti u žalbenom postupku. Neophodno je, u ovom slučaju, omogućiti DKOM-u da žalbu ispituje i mimo žalbenog zahtjeva, po uzoru na §. 114. st. 1. GWB-a. Međutim, prihvaćanje ovog rješenja značilo bi i praktično odustajanje od koncepta upravnih ugovora kakav je zamišljen pri donošenju ZUP-a 2010. godine. Ipak, kada promotrimo uspjeh primjene norme iz ZUP-a glede upravnih ugovora, možda se vrijedi upitati treba li zadržati takav model ili bi trebalo razmisliti o novom, drugačijem modelu.

Postoji i još jedno moguće rješenje, za koje smatram da je možda i najlošije, ali, poučen dosadašnjim iskustvima, mislim da je možda i najvjerojatnije. Naime, sasvim je moguće ostaviti situaciju kakva jest, uz minimalne izmjene, kako bi se spriječilo nastajanje teških posljedica. U tom rješenju ZUP se ne bi mijenjao, nego bi se interveniralo u posebno zakonodavstvo na način da bi se izričito propisalo da se protiv rješenja DKOM-a ne može pokrenuti upravni spor, nego da se sudska zaštita ostvaruje pred redovnim sudom te da se ugovori o koncesijama, javnoj nabavi i sl. ne mogu osporavati pred upravnim sudovima. Na taj način spriječio bi se dualitet u sudskoj nadležnosti, kao i mogućnost sukoba nadležnosti i različitih postupanja sudova, što je sada, kako sam pokazao, moguće. Međutim, ovo rješenje ne rješava problem poništavanja rješenja nakon što je ugovor već sklopljen, pa bi bilo potrebno u posebnom zakonodavstvu propisati suspenzivni učinak tužbe.

Prema tome, kako bismo unaprijedili kontrolu sklapanja upravnih ugovora, moramo, prvenstveno, riješiti dileme oko pravne prirode određenih ugovora, jasnije definirati upravne ugovore u našem pravu i uspostaviti adekvatniji i brži sustav kontrole. Naravno, neophodno je osigurati i adekvatnu kontrolu izvršavanja javnih ugovora. Tada ćemo moći reći da je osigurana zakonitost pri sklapanju upravnih ugovora.

57 „U prijedlogu za obnovu postupka stranka je dužna učiniti vjerojatnim razloge zbog kojih traži obnovu postupka i da je prijedlog podnesen u zakonskom roku“ - čl. 124., st. 2. ZUP-a.

„Kad nadležno tijelo primi prijedlog za obnovu postupka, dužno je ispitati je li prijedlog pravodoban i izjavljen od ovlaštene osobe te je li okolnost na kojoj se prijedlog temelji učinjena vjerojatnom. Ako ti uvjeti nisu ispunjeni, nadležno tijelo odbacit će prijedlog rješenjem“ - čl. 126., st. 1. ZUP-a. 


\section{Literatura}

1. Borković, I., „Upravni ugovori“, Zbornik Pravnog fakulteta u Splitu, god 30/2, 1993., str. 417-434.

2. Burgi, M., Public procurement law in the Federal Republic of Germany, Annual report - 2012 - Germany.

3. Comba, M. E., „Contract Execution in Europe: Different Legal Models with a Common Core“, European Procurement \& Public Private Partnership Law Review, 4/2013., str. 302-308.

4. Crnković, M., „Upravni ugovori u posebnom zakonodavstvu Republike Hrvatske“, Hrvatska i komparativna javna uprava, 14 (2014.), br. 4., str. 1035-1056.

5. Detterbeck, S., Öffentliches Recht, Verlag Franz Vahlen, München, 2009.

6. Đerđa, D., „Koncesije“, Hrvatska pravna revija, br. 2/2015., str. 55-64.

7. Đerđa, D., „Opće pravno uređenje koncesija u Republici Hrvatskoj“, Hrvatska pravna revija, br. 6/2015., str. 37-50.

8. Đerđa, D., „Posebnosti upravnih ugovora“, Hrvatska pravna revija, br. 10/2008., str. 58-69.

9. Đerđa, D., „Pravno uređenje koncesija u pravu Europske unije“, Hrvatska pravna revija, br. 3/2015., str. 45-53.

10. Đerđa, D., Upravni ugovori u hrvatskom pravu, Informator br. 5809, str. 1-12.

11. Frier, P-L:, Precis de droit administratif, Montchrestien, 2003.

12. Johlen, H., Verwaltungsrecht, Verlag C.H. Beck, München, 2009.

13. Kirchof, P. i Kruter-Kirchof, C., Staats- und Verwaltungsrecht Bundesrepublik Deutschland, C.F. Muller Verlag, Heilderberg, 2009.

14. Koprić, I., Nikšić, S., „Upravni ugovori, područje primjene i primjena prava“, Zbornik susreta pravnika Opatija 48., str. 271-303.

15. Medvedović, D., „Bitne razlike novog ZUP-a prema prijašnjem ZUP-u“, u: Primjena Zakona o općem upravnom postupku, Informator, Zagreb, 2010., str. 397-432.

16. Mozzati, A., Afferni, G., „Recent developments in the European law of public contracts“, European Review of Contract Law, 4/2011., str. 552-566.

17. Pejaković, S., ,Je li ugovor o javnoj nabavi upravni ugovor“, Informator, br. 6171, str. 1-3. i Informator, br. 6172-6173, str. 13. i 14.

18. Pirnat, R., „Upravni ugovor i upravni postupak“, u: Modernizacija općeg upravnog postupka i javne uprave u Hrvatskoj, Suvremena javna uprava, Zagreb, 2009., str. 111-122.

19. Racca, G. M., Cavallo Perin, R., „Material Amendments of Public Contracts during their Terms“, European Procurement \& Public Private Partnership Law Review, 4/2013, str. 279-293.

20. Richer, L., Droit des contrats administratifs, L.G.D.J. Paris, 2008.

21. Staničić, F., „Učinak vođenja upravnog spora na izvršnost upravnih odluka: privremene mjere i odgodni učinak tužbe“, Zbornik radova Pravnog fakulteta u Splitu, vol 52, br. 1., 2014., str. 159-173. 
22. Šikić, M., Staničić, F., „Pravna narav ugovora o koncesiji“, Zbornik radova Pravnog fakulteta u Splitu, 48 (2011.), 2., str. 419-441.

23. Šprajc, I., „O važnosti jednog rješenja Državne komisije za kontrolu postupaka javne nabave“, Hrvatska pravna revija, br. 5/2015., str. 50-53.

Pravni propisi

1. Direktiva 2004/18/EC, SL L 134 od 30. travnja 2004.

2. Direktiva 2004/17/EC, SL L 134 od 30. travnja 2004.

3. Direktiva 2014/24/EU, SL L 94/65 od 26. veljače 2014.

4. Direktiva 2014/23/EU, SL. L. 94/1 od 28. ožujka 2014.

5. Direktiva 2007/66/EC, SL. L. 335/31 od 20. prosinca 2007.

6. Zakon o općem upravnom postupku, NN 47/09.

7. Zakon o upravnim sporovima, NN 20/10, 143/12 i 152/14.

8. Opći porezni zakon, NN 147/08, 18/11, 78/12, 136/12, 73/13 i 26/15.

9. Zakon o koncesijama, NN 143/12.

10. Zakon o javnoj nabavi, NN 90/11, 83/13, 143/13 i 13/14.

11. Zakon o Državnoj komisiji za kontrolu postupaka javne nabave, NN 18/13, $127 / 13,74 / 14$.

12. Zakon o javno-privatnom partnerstvu, NN 78/12 i 152/14.

13. Zakon o zaštiti tržišnog natjecanja, NN 79/09 i 80/13.

14. Verwaltungsverfahrengesetz (VwVfG), BGBl. I S. 102, BGBl. I S. 2749.

15. Gesetz gegen Wettbewerbsbeschränkungen (GWB), BGBI I 2546.

16. Verordnung über die Vergabe öffentlicher Aufträge (Vergabeverordnung VgV), BGBl. I S. 169, BGBl. I S. 1474. 


\section{CONTROL OVER ADMINISTRATIVE CONTRACT FORMATION}

Administrative contracts in Croatian legislation represent a novelty introduced into the General Administration Procedure Act in 2010. This is a novelty which has not proved to be successful in practice. Control over administrative contract formation is inevitable and is very significant for a number of reasons. Firstly, public legal bodies which form them do so by exercising their own public powers which are without doubt subject to legality control; secondly, in forming administrative contracts, public funds are used which must be controlled; thirdly, forming administrative contracts often touches on using public goods. Due to the restrictive interpretation of administrative contracts in Croatian legislation, this institute is indisputably only regulated in the General Taxation Act. However, for more than two decades contracts which satisfy all presumptions have existed in our law in order to be considered as administrative contracts. It is for this reason that control over contracts will be dealt with for contracts considered by the author to be administrative contracts. These are contracts on concessions and contracts on public procurement. How inadequate today's regulation of control of administrative contract formation is will be demonstrated, particularly regarding contracts on concession and public procurement. Legislative changes will be proposed which should result in a more quality system of control over administrative contract formation. How control over administrative contract formation cannot be considered as separate from control over administrative contract execution will also be shown.

Key words: administrative contract, contract on concession, contract on public procurement, control over legality 